\title{
Survival, Weight, and Prolificacy of Eisenia fetida (Savigny 1826) in Relation to Food Type and Several Soil Parameters
}

\author{
Mădălina Iordache* \\ University of Agricultural Sciences and Veterinary Medicine of Banat King Michael the ${ }^{\text {It }}$ of Romania, \\ Faculty of Agriculture, Department of Sustainable Development and Environmental Engineering, \\ 119 Calea Aradului Street, 300645 Timişoara, Romania
}

Received: 23 April 2017

Accepted: 15 June 2017

\begin{abstract}
The management of plant wastes represents an issue to be solved as efficiently as possible. The main objectives of this study were to show that wastes like decomposed fruits of Solanum lycopersicum L. (tomato) can be managed by introducing them to the diet of the earthworm Eisenia fetida (Savigny 1826) (red wiggler worm), and to determine the relationship between this earthworm's weight and prolificacy and several soil properties. The results of this three-month laboratory experiment revealed that the decomposed tomato fruits represent an adequate food for Eisenia fetida: no mortality was recorded; the soil containing earthworms fed with this food recorded statistically significant increases of $\mathrm{pH}$ (from 7.89 to $7.96, \mathrm{p}<0.05$ ), total nitrogen (from $0.21 \%$ to $0.24 \%, \mathrm{p}<0.01, \mathrm{p}<0.05$ ), and available potassium (from 188.33 to $291 \mathrm{mg} \cdot \mathrm{kg}^{-1}, \mathrm{p}<0.01, \mathrm{p}<0.05$ ) as compared to the soil containing earthworms not fed with tomatoes. A strong positive correlation between the weight of earthworms fed with tomatoes and the concentration of the available phosphorus of soil was found (Spearman and Kendall Correlations: $p<0.01$ ), along with a strong negative correlation between the weight of earthworms fed with tomatoe fruits and the concentration of the available potassium of soil (Spearman Correlation: $\mathrm{p}<0.01$ ). A positive correlation was observed between the prolificacy of earthworms fed with fruits of tomatoes and the $\mathrm{pH}$ of the adjacent soil (Pearson Correlation: $\mathrm{p}=0.052$ ). In conclusion, Eisenia fetida tolerates very well the decomposed fruits of tomatoes as food, and its survival, weight, and prolificacy depend on it and on the analyzed soil parameters.
\end{abstract}

Keywords: mortality, prolificacy, phosphorus, potassium, total nitrogen

\section{Introduction}

Earthworms are ubiquitous organisms living in soil that play a significant role in soil formation and the circuit

*e-mail: mada_iordache@yahoo.com of nutritive substances. Due to their digging activity through soil, detritus consumption, and organic material decay, these organisms improve several physical and chemical properties of soil.

In the management of waste, current studies show that earthworms are essential for many species. Earthworms can reduce the duration of the composting process, decrease the $\mathrm{C}: \mathrm{N}$ ratio, and offer compost products with 
higher quality [1-4]. Wastes like decomposed or fresh fruits and vegetables can be recycled using earthworms. Numerous studies have been performed on this topic. Huang et al. (2016) [5] tried to recycle banana peels, cabbage, lettuce, potatoes, and watermelon peels using the earthworm species Eisenia fetida (Savigny 1826) (red wiggler worm). His experiments succeded with one exception: banana peels, which were harmful to the worms. The same study demonstrated that Eisenia fetida could broaden the bacterial diversity in the final degradation product - especially the populations of actinobacteria and ammonia-oxidizing bacteria. Jyoti and Seema (2014) [6] carried out a laboratory experiment for the management of a solid waste (mixtures of solid waste and cow dung) through the action of the earthworm Metaphire posthuma (Vaillant 1868). After 15 days of experiments they found that earthworms accelerated the decomposition of wastes and that earthworms can recycle the solid waste into useful nutrients. A negative trend of $\mathrm{pH}$, organic matter, and $\mathrm{C}: \mathrm{N}$ ratio were recorded, but the total nitrogen, phosphorus, and potassium content expressed increments - clearly indicating the earthworm biotechnology in recycling of waste and nutrient enrichment as vermicompost. Deivanayaki and Sathya (2015) [7] studied several soil parameters such as $\mathrm{pH}$, macronutrients $(\mathrm{N}, \mathrm{P}$, and $\mathrm{K}$ ), and micronutrients $(\mathrm{Fe}, \mathrm{Mn}, \mathrm{Cu}$, and $\mathrm{Zn})$ present in the vermicomposts obtained from green gram (Vigna radiata (L.) Wilczek) wastes after using them by earthworms Eisenia fetida. The $\mathrm{pH}$ values of the vermicompost obtained after 35 days of vermicomposting showed a lower $\mathrm{pH}$ value than that of raw decomposed green gram. The level of $\mathrm{N}$ and $\mathrm{P}$ slightly increased, and the level of K drastically decreased. Liu et al. (2012) [8] evaluated the relationships established between Eisenia fetida and heavy metals in sewage sludge, and they found that water content of the substrate, the value of $\mathrm{pH}$, and the content of organic matter decreased, whereas the concentration of total nitrogen, available nitrogen, and available phosphorus increased, and the content of total phosphorus and total potassium decreased.

The research aimed to establish the influence of the food type represented by decomposed fruits of Solanum lycopersicum L. (tomato) upon several biological characteristics (survival, body weight, prolificacy) of Eisenia fetida, respectively to establish the relationships existing between these biological characteristics and several soil properties $(\mathrm{pH}$, total nitrogen, available potassium, available phosphorus) within a laboratory experiment.

\section{Materials and Methods}

The research was carried out within a laboratory experiment (microcosmos) organized at the University of Agricultural Sciences and Veterinary Medicine of Banat King Michael the I ${ }^{\text {st }}$ of Romania from Timişoara, Romania. The experiment lasted three months. The microclimate conditions consisted of $20 \pm 2^{\circ} \mathrm{C}$ environ- mental temperature and the natural photoperiod characteristic to the months that represented the research interval, respectively November, December, and January of the zone $\left(45^{\circ} 45^{\prime} \mathrm{N} 21^{\circ} 14^{\prime} \mathrm{E}\right)$.

The microcosmos experiment has been carried out in control boxes (Eisenia fetida not fed with decomposed fruits of Solanum lycopersicum) and in test boxes (Eisenia fetida fed with decomposed fruits of Solanum lycopersicum), and was established in three replicates.

Each experimental box was filled with soil in the amount of 1,660 g. The soil used within the experiment was a cambic chernozem (FAO System) collected from the first $30 \mathrm{~cm}$ of topsoil $(2.97 \%$ content of total organic carbon), cleaned by plants and other rests, and analyzed with a magnifying glass in order to eliminate the earthworm cocoons and other impurities.

Into each box were introduced 10 Eisenia fetida earthworms. They were adults and their body weights ranged between 4.49-5.86 g, without significant differences between weight values.

Nutritive substrate as decomposed fruits of Solanum lycopersicum (tomatoes) was added into the test boxes and was prepared as follows: fruits of Solanum lycopersicum were chopped and left at room temperature for a week, resulting in a product that has been preserved in a freezer $\left(-15^{\circ} \mathrm{C}\right)$ and used for the subsequent feeding of earthworms; each feeding was realized with $40 \mathrm{~g}$ of tomatoes for each box.

The moments when the nutritive substrate was added in the test boxes were:

- Six days from the moment when earthworms were introduced in boxes (from the start of the experiment).

- Forty-five days after the moment when earthworms were introduced into the boxes (at the halfway point of the experiment).

Moisture content was controlled one time per week by adding distilled water in order to maintain humidity content between 70 and $80 \%$. Moisture content was established by drying a substrate sample at $105^{\circ} \mathrm{C}$ for $48 \mathrm{~h}$.

In order to distinguish the influence of the food (decomposed fruits of Solanum lycopersicum) on Eisenia fetida, and also the influence of Eisenia fetida (fed or not with this food) on soil characteristics, the following parameters were monitored:

- Body weight of earthworms at the start and at the end of the experiment, in control boxes and in test boxes, respectively.

- Earthworm mortality (as earthworms found alive) at the start and at the end of the experiment, in control boxes and in test boxes.

- Earthworm prolificacy (hatched larvae) at the end of the experiment, in control boxes and in test boxes.

- The variation of values for the following parameters of soil: $\mathrm{pH}$, total nitrogen, available potassium, and available phosphorus (in all boxes - control and test).

The number of earthworms and hatchlings were counted by hand sorting. The parameters of soil $(\mathrm{pH}$, total nitrogen, available potassium, and available phosphorus) 
were established using the following methodology: the $\mathrm{pH}$ values have been established by the potentiometric method in aqueous suspension $\left(\mathrm{pH}_{\mathrm{H}_{2} \mathrm{O}}\right)$, ratio soil:solution was 1:2.5; the content in total nitrogen of soil using the Kjeldahl method; the mobile (plant available) phosphorus and potassium of soil have been determined by spectrophotometry and flame spectrometry methods, respectively, by the Egner-Riehm-Domingo method [9]. Statistical processing was realized using Statistical Package for the Social Sciences software.

\section{Results and Discussion}

At the end of the experiment, in the control boxes $8.33 \pm 2.08$ earthworms were found alive, meaning a mortality of $16.7 \%$ in relation to the initial number (10) of earthworms introduced into the boxes. In the boxes where earthworms were fed with decomposed fruits of tomatoes, at the end of the experiment no mortality was recorded, which means that this type of food was well accepted by the earthworms (Table 1).

At the end of the experiment a decrease of $58.78 \%$ in the mean value of earthworm body weight in the control boxes compared with values recorded at the beginning of the experiment was noticed. The same situation also was found in the test boxes with earthworms fed with tomato fruits, but in this case the decrease was lower: $55.54 \%$ as compared to the earthworm weight at the beginning of the experiment (Table 1). The loss of earthworm weight in this study is considered to be due to water loss. Several authors have found that the most important factor influencing water content of the earthworm body is the maintenance conditions of the worm prior to analysis [10] or depending on environmental conditions [11] (for example, earthworms often lose weight or enter diapause when soils are too dry [12-13]. It was found that the proper functions of the organism are not seriously affected by losses of water up to $18 \%$, although $70-75 \%$ of earthworm weight can be lost without killing the worm [14]. The earthworms used within the experiment were translocated from a very moist environment $(60 \%$ of gravimetric moisture content) into a soil with $40 \%$ moisture, and they lost weight in this second environment. Also, earthworms consume water for respiration, to produce mucus to avoid drying, and to move through the soil [15], so that the loss of weight is a physiological effect and not a response to an inhibitory condition [16]. Excluded the stress caused by the experimental conditions in weight loss because prolificacy was high. Many studies have shown that earthworms gain or lose weight depending on environmental moisture [17-19]. Richardson et al. (2009) [20] found that the species Amynthas agrestis (Goto and Hatai 1899) survived with more success in higher temperatures of soil when the moisture of soil was appropriate, which increased the survival of the species and decreased the weight loss, and the maintenance of the fresh body weight depends on moisture degree of soil. When earthworms were taken from soil and placed in water they usually gained weight [21]. Matos-Moreira et al. (2012) [22] found significant increases of body mass in Eisenia fetida when exposed to high concentrations of organic wastes. Earthworms often lose body weight or reach diapause when soil moisture is too low. Bayley et al. (2010) [23] reported a decrease by $50 \%$ of water content of the body for the species Apporectodea caliginosa (Savigny 1826) during its estivation. However, losing weight in soil is a faster process than gaining weight in water [21].

At the end of the experiment the body weight of earthworms fed with fruits of Solanum lycopersicum was $9.56 \%$ higher than that of the earthworms from the control boxes because of the surplus of organic matter provided by the macerated fruits of tomatoes offered as food.

Data regarding the prolificacy of earthworms have been reported as the number of hatched larvae at the end of the experiment - both in control and test boxes. Thus, at the end of the experiment it was found that prolificacy of earthworms fed with tomatoes was much higher than that of the unfed earthworms in the control boxes. The earthworm prolificacy considerably increased, on average from 6 to 41 cocoons, after being fed with tomato fruits. The one-way ANOVA Test and paired sample T-test showed significant correlations for these findings (Table 1).

The analyzed parameters of the soil from the control and test boxes were $\mathrm{pH}$, total nitrogen, available potassium, and available phosphorus (Table 2). The

Table 1. Mortality, body weight, and prolificacy of the species Eisenia fetida within the experiment.

\begin{tabular}{|c|c|c|c|c|c|}
\hline \multirow{2}{*}{$\begin{array}{c}\text { Experimental } \\
\text { variant }\end{array}$} & \multicolumn{2}{|c|}{ Mortality } & \multicolumn{2}{c|}{ Body weight } & Prolificacy \\
\cline { 2 - 6 } & $\begin{array}{c}\text { Earthworm } \\
\text { number at start }\end{array}$ & $\begin{array}{c}\text { Earthworm } \\
\text { number at end }\end{array}$ & $\begin{array}{c}\text { Earthworm } \\
\text { weight at start } \\
(\mathrm{g})\end{array}$ & $\begin{array}{c}\text { Earthworm } \\
\text { weight at end } \\
(\mathrm{g})\end{array}$ & $\begin{array}{c}\text { Number of hatched } \\
\text { larvae after 3 } \\
\text { months }\end{array}$ \\
\hline Control & 10 & $8.33 \pm 2.08$ & $5.07 \pm 0.51$ & $2.09 \pm 0.63$ & $6.00 \pm 1.73 *$ \\
\hline Standard error & 0 & 1.47 & 0.36 & 0.44 & 1.22 \\
\hline Fruits of Solanum lycopersicum & 10 & 10 & $5.15 \pm 0.20$ & $2.29 \pm 0.12$ & $41 \pm 6.08^{*}$ \\
\hline Standard error & 0 & 0 & 0.14 & 0.08 & 4.30 \\
\hline
\end{tabular}

*One-way ANOVA $(\mathrm{p}<0.05): \mathrm{F}(1.4)=91.875, \mathrm{p}=0.001$; paired sample T-test $(\mathrm{p}<0.05)$ : $\mathrm{t}(2)=-7.762, \mathrm{p}=0.016$ 
Table 2. Physical-chemical properties of the soil of the experimental variants.

\begin{tabular}{|c|c|c|}
\hline Experimental variant & Indicator & Values \\
\hline \multirow{4}{*}{$\begin{array}{c}\text { Soil without Eisenia } \\
\text { fetida }\end{array}$} & $\mathrm{pH}(\mathrm{pH}$ units) & $7.89 \pm 6.08$ \\
\cline { 2 - 3 } & $\mathrm{Nt}(\%)$ & $0.15 \pm 2.51$ \\
\cline { 2 - 3 } & $\mathrm{P}\left(\mathrm{mg} \cdot \mathrm{kg}^{-1}\right)$ & $18.14 \pm 0.13$ \\
\cline { 2 - 3 } & $\mathrm{K}\left(\mathrm{mg} \cdot \mathrm{kg}^{-1}\right)$ & $220.66 \pm 6.11$ \\
\hline \multirow{4}{*}{\begin{tabular}{c} 
Soil with Eisenia fetida \\
\cline { 2 - 3 }
\end{tabular}} & $\mathrm{pH}(\mathrm{pH}$ units) & $7.79 \pm 6.02^{1}$ \\
\cline { 2 - 3 } & $\mathrm{Nt}(\%)$ & $0.21 \pm 1.52^{2}$ \\
\cline { 2 - 3 } & $\mathrm{P}\left(\mathrm{mg} \cdot \mathrm{kg}^{-1}\right)$ & $36.15 \pm 2.76^{3}$ \\
\hline \multirow{3}{*}{$\begin{array}{c}\text { Soil with Eisenia } \\
\text { fetida fed with fruits of } \\
\text { Solanum lycopersicum }\end{array}$} & $\mathrm{kH}(\mathrm{pH} \mathrm{units})$ & $188.33 \pm 20.00^{4}$ \\
\cline { 2 - 3 } & $\mathrm{Nt}(\%)$ & $7.96 \pm 3.46^{1}$ \\
\cline { 2 - 3 } & $\mathrm{K}\left(\mathrm{mg} \cdot \mathrm{kg}^{-1}\right)$ & $28.68 \pm 3.75^{3}$ \\
\cline { 2 - 3 } & $\left.\mathrm{kg} \cdot \mathrm{kg}^{-1}\right)$ & $291.00 \pm 9.64^{4}$ \\
\hline
\end{tabular}

${ }^{1}$ One-way ANOVA $(\mathrm{p}<0.05): \mathrm{F}(1.4)=16.559, \mathrm{p}=0.015$; paired sample T-test $(\mathrm{p}<0.05): \mathrm{t}(2)=-7.472, \mathrm{p}=0.017$; ${ }^{2}$ One-way ANOVA $(\mathrm{p}<0.05): \mathrm{F}(1.4)=9.091, \mathrm{p}=0.039$; paired sample T-test $(\mathrm{p}<0.05): \mathrm{t}(2)=-10.000, \mathrm{p}=0.010$; ${ }^{3}$ One-way ANOVA $(\mathrm{p}<0.05)$ : $\mathrm{F}(1.4)=7.705, \mathrm{p}=0.050$; paired sample T-test $(\mathrm{p}<0.05): \mathrm{t}(2)=15.403, \mathrm{p}=0.004$; ${ }^{4}$ One-way ANOVA $(p<0.05): F(1.4)=64.097, p=0.001$; paired sample T-test $(\mathrm{p}<0.05)$ : $\mathrm{t}(2)=-6.073, \mathrm{p}=0.026$.

results of the study showed that the soil containing earthworms fed with tomato fruits recorded statistically significant increases (one-way ANOVA statistics, paired sample T-test statistics, $\mathrm{p}<0.05$ ) of $\mathrm{pH}$, total nitrogen and available potassium, respectively a decrease of the available phosphorus as compared to the soil containing earthworms not fed with tomato fruits (Table 2). In the boxes where tomatoes were added, the $\mathrm{pH}$ value recorded a slight rise, on average by $2.18 \%$. Musaida et al. (2012) [24] showed that this increase is possibly due to nitrogenous waste excreted by the earthworms.
Asadollahfardi and Mohebi (2012) [25], after an 80-day experiment using Eisenia fetida to change fruit and vegetable residues amended with straw wheat, horse manure, shred white paper, and egg shells through vermicomposting, found a decrease of substrate $\mathrm{pH}$ and an increase in total nitrogen, phosphorus, and $\mathrm{Fe}$, and not only no earthworm mortality, but an increase in earthworm numbers.

The concentration of total nitrogen increased by $14.28 \%$, and the concentration of available potassium by $54.51 \%$. The increase of nitrogen content is due to nitrogenous metabolic products of earthworms, which were returned to the vermicompost as casts and urine, as also observed Muthukumaravel et al. (2008) [26]. Ansari and Rajpersaud (2012) [27] showed that the increase of potassium is due to earthworm activity in mineralization and mobilization of phosphorus.

Relating these findings to those recorded in the soil without earthworms, the increase of values for the analyzed parameters of soil were even higher (Table 2). Correlations between body weight and prolificacy of earthworms fed with tomato fruits and the concentrations of several chemical parameters of the adjacent soil were found. Thus, a strong positive correlation between the body weight of the earthworms fed with tomatoes and the concentration of the available phosphorus of soil, and a strong, negative correlation between the body weight of the earthworms fed with tomatoes and the concentration of the available potassium of soil (Table 3) (Spearman's and Kendall's Correlations, $\mathrm{p}<0.01$ ) also were found.

A positive correlation was observed between the prolificacy of earthworms fed with fruits of tomatoes and the $\mathrm{pH}$ of the adjacent soil (Pearson's Correlations, $\mathrm{p}<0.05$ ). The presence of Eisenia fetida in soil determines the improvement of several parameters of it - even in the case when earthworms were not fed with tomato fruits - as follows: the concentration of total nitrogen increased by $40 \%$, the concentration of available phosphorus nearly doubled, and the concentration of available potassium decreased (14.66\%) (one-way

Table 3. Correlations between body weight and prolificacy of Eisenia fetida earthworms fed with fruits of Solanum lycopersicum, and the concentrations of mobile phosphorus and potassium of the adjacent soil (Spearman and Kendall Correlations: $\mathrm{p}<0.01$, Pearson Correlation: $\mathrm{p}<0.05$ ).

\begin{tabular}{|c|c|c|}
\hline \multirow{2}{*}{$\begin{array}{c}\text { Correlations between body weight of the earthworms fed with } \\
\text { tomato fruits and the concentration of the mobile phosphorus } \\
\text { of soil }\end{array}$} & Kendall's Correlation Coefficient & $1.000^{* *}$ \\
\cline { 2 - 3 } & Sig. (two-tailed) & .000 \\
\cline { 2 - 3 } & Spearman's Correlation Coefficient & $1.000^{* *}$ \\
\hline \multirow{2}{*}{$\begin{array}{c}\text { Correlations between body weight of the earthworms fed } \\
\text { with tomato fruits and the concentration of the mobile } \\
\text { potassium of soil }\end{array}$} & Spearman's Correlation Coefficient & -1.000 \\
\cline { 2 - 3 } $\begin{array}{c}\text { Sorrelations between the prolificacy of the earthworms } \\
\text { fed with tomato fruits and the pH of soil }\end{array}$ & Pearson's Correlation Coefficient & .000 \\
\cline { 2 - 3 } & Sig. (two-tailed) & 0.997 \\
\hline \multirow{2}{*}{\begin{tabular}{c} 
Con \\
\cline { 2 - 3 }
\end{tabular}} & & 0.052 \\
\hline
\end{tabular}

\footnotetext{
**Correlation is significant at the 0.01 level (two-tailed)
} 
ANOVA and paired sample T-test, $\mathrm{p}<0.05$; Table 2). On the contrary, in the soil containing earthworms fed with tomato fruits, the values of available phosphorus decreased and available potassium increased.

The increase of nitrogen concentration in the presence of Eisenia fetida in waste management was often observed [1-2, 4, 28-30]. The increase of phosphorus in the presence of Eisenia fetida in different waste media also has been reported by other studies: in fly ash-cow dung-paper waste vermicompost [31], in waste from the sugar industry $[4,28]$, in waste paper and chicken manure [30], or in bio-waste like sewage sludge and rabbit manure [2]. The decrease of potassium in soil in the presence of earthworms was previously found in field literature [32-34], and this aspect necessitates further investigation. The findings of Sangwan et al. (2008) [35] cited by Pattnaik and Reddy (2009) [36] reported a decrease in potassium content in the vermicompost produced by Eisenia fetida as compared to that of the substrate. Zirbes et al. (2011) [37] noted an important decrease in total potassium (ranging between 1.85 and 28.99\%) for six vermicompost substrates consisting of water hyacinth (Eichhornia crassipes (Mart) Solms) and pig manure in various proportions (from 100\% water hyacinth to $100 \%$ pig manure) in the presence of the species Perionyx excavatus (Perrier 1872). Liu et al. (2005) [38] studied the potential of Eisenia fetida to improve the fertility of soil by comparing sewage sludge with and without earthworm treatment, and their results showed that earthworm activity had no significant effect on the contents of total and available potassium.

In assessing the results, the contribution of the fruits of Solanum lycopersicum, which in small amounts remained unconsumed by earthworms and which, also in small measure, is possible to represent a source for the analyzed chemical elements in the soil, must also be considered.

The $\mathrm{pH}$ values slightly decreased in the soil with unfed Eisenia fetida, but the statistical processing does not confirm that this fact is due to earthworm activity (Table 2). This could be because of the vermiwash released in the process. Musaida et al. (2012) showed that this vermiwash increases the moisture content, thus neutralizing the $\mathrm{pH}$ of the vermicompost [27]. However, the decrease of $\mathrm{pH}$ values in vermicompostation with Eisenia fetida was observed also by Kashi and Khoshab (2015) [39] within an experiment by 45-60 days using different types of agricultural wastes (pine sawdust and cotton industry waste, as bulking agent), types of farm animal manure (poultry litter and horse manure, as regulator agent), and municipal solid waste. Suthar and Gairola (2014) [34] reported as well the decrease of $\mathrm{pH}$ when the species Eisenia fetida was used to recycle leaf litter waste solids (silver oak and bamboo) combined with cow dung. The decrease of $\mathrm{pH}$ also has been recorded for other species of earthworms $[6,40-41]$.

\section{Conclusions}

This study revealed the following: the decomposed fruits of Solanum lycopersicum represent an adequate food for Eisenia fetida. No mortality was recorded among earthworms fed with this food. At the end of the experiment, the body weight of earthworms fed with fruits of Solanum lycopersicum was higher than that of the earthworms from the control boxes, due to the surplus of organic matter provided by this type of food, and the fact that the prolificacy of earthworms considerably increased over that of the unfed earthworms in the control boxes has been established. Significant statistical correlations supporting this finding were found. The soil containing earthworms fed with fruits of Solanum lycopersicum recorded statistically significant increases of $\mathrm{pH}$, total nitrogen, and available potassium, respectively, and a decrease of the available phosphorus as compared to the soil containing earthworms not fed with tomato fruits. The presence of earthworms in soil determined the improvement of several parameters of it, even in the case when earthworms were not fed with fruits of Solanum lycopersicum: the concentration of total nitrogen increased by $40 \%$, the concentration of available phosphorus nearly doubled, and the concentration of available potassium decreased (14.66\%).

\section{References}

1. GARG V.K., GUPTA R. Effect of Temperature Variations on Vermicomposting of Household Solid Waste and Fecundity of Eisenia fetida. Bioremediat. J. 15 (3), 165, 2011.

2. JOSE MOLINA M., DESAMPARADOS SORIANO M., INGELMO F., LLINARES J. Stabilisation of sewage sludge and vinasse bio-wastes by vermicomposting with rabbit manure using Eisenia fetida. Bioresour. Technol. 137, 88, 2013.

3. YADAV A., GARG V.K. Nutrient recycling from industrial solid wastes and weeds by vermiprocessing using earthworms. Pedosphere. 23 (5), 668, 2013.

4. BHAT S.A., SINGH J., VIG A.P. Potential utilization of bagasse as feed material for earthworm Eisenia fetida and production of vermicompost. Springerplus. 4, 11, 2015.

5. HUANG K., XIA H., LI F.S., WEI Y.F., CUI G.Y., FU X.Y., CHEN X.M. Optimal growth condition of earthworms and their vermicompost features during recycling of five different fresh fruit and vegetable wastes. Environ. Sci. Pollut. Res. 23 (13), 13569, 2016.

6. JYOTI V.S., SEEMA R. Potential of earthworms in bioconversion of organic solid waste. In Climate Change and Biodiversity, Series Advances in Geographical and Environmental Sciences; Singh M., Singh R.B., Hassan M.I., Eds., Springer: Rohtak, India, 1, 175, 2014.

7. DEIVANAYAKI M., SATHYA R. Macro and micronutrient analysis of vermicompost obtained from greengram wastes. Indian. J. Sci. 15 (45), 27, 2015.

8. LIU F., ZHU P., XUE J. Comparative study on physical and chemical characteristics of sludge vermicomposted by Eisenia fetida. Procedia Environ. Sci. 16, 418, 2012. 
9. EGNER H., RIEHM H., DOMINGO W.R. Studies concerning the chemical analysis of soils as background for soil nutrient assessment. II. Chemical extracting methods to determinate the phosphorus and potassium content of soil. Kungliga Lantubrukshögskolans annaler. 26, 199, 1960 [In German]

10. OGLESBY L. Inorganic components and metabolism; Ionic and osmotic regulation: Annelida, Sipuncula, and Echiura. Steady-State water and solute concentrations. In Chemical Zoology: Annelida, Echiuria, and Sipuncula; Florkin M., Scheer B.T., Eds., Academic Press: New York, USA, Volume 4, 239, 2012.

11. PERREAULT J.M., WHALEN J.K. Earthworm burrowing in laboratory microcosms as influenced by soil temperature and moisture. Pedobiologia. 50, 397, 2006.

12. BOOTH L.H., HEPPELTHWAITE V., MCGLINCHY A. The effect of environmental parameters on growth, cholinesterase activity and glutathione S-transferase activity in the earthworm (Aporrectodea caliginosa). Biomarkers. 5, 46, 2000.

13. HOLMSTRUP M. Sensitivity of life history parametersin the earthworm Aporrectodea caliginosa to small changes in soil water potential. Soil Biol. Biochem. 33, 1217, 2001.

14. SINGH N.B., KHARE A.K., BHARGAVA D.S., BHATTACHARYA S. Optimum moisture requirement during vermicomposting using Perionyx excavatus. Appl. Ecol. Env. Res. 2 (1), 53, 2004.

15. JACOB P., MCDANIEL K.A., BARBARICK M.E., STROMBERGER W.C. Survivability of in response to drought stress in a Colorado soil. Soil Sci. Soc. Am. J. 77 (5), 1667, 2013.

16. KREUTZWEISER D.P., GOOD K.P., CHARTRAND D.T., SCARR T.A., HOLMES S.B., THOMPSON D.G. Effects on litter-dwelling earthworms and microbial decomposition of soil-applied imidacloprid for control of woodboring insects. Pest. Manag. Sci. 64 (2), 112, 2008.

17. LIMA M.P.R., SOARES A.M.V.M., LOUREIRO S. Combined effects of soil moisture and carbaryl to earthworms and plants: simulation of flood and drought scenarios. Environ. Pollut. 159 (7), 1844, 2011.

18. GORRES J.H., BELLITURK K., MELNICHUK R.D.S. Temperature and moisture variables affecting the earthworms of genus Amynthas Kinberg, 1867 (Oligachaeta: Megascolecidae) in a hardwood forest in the Champlain Valley, Vermont, USA. Appl. Soil. Ecol. 104, 111, 2016.

19. KANEDA S., OHKUBO S., WAGAI R., YAGASAKI Y. Soil temperature and moisture-based estimation of rates of soil aggregate formation by the endogeic earthworm Eisenia japonica (Michaelsen, 1892). Biol. Fertil. Soils. 52 (6), 789, 2016.

20. RICHARDSON D.R., SNYDER B.A., HENDRIX P.F. Soil moisture and temperature: tolerances and optima for a non-native earthworm species, Amynthas agrestis (Oligochaeta: Opisthopora: Megascolecidae). Southeast. Nat. 8 (2), 325, 2009.

21. LAVERACK M.S. The physiology of earthworms. In International Series of Monographs on Pure and Applied Biology: Zoology; Kerkut G.A., Ed., Pergamon Press: New York, USA, 206, 2013

22. MATOS-MOREIRA M., CARRAL E., TERESA RODRIGUEZ M., LOPEZ-MOSQUERA M.E. Survival, body mass change and metal bioaccumulation in Eisenia fetida (Oligochaeta: Lumbricidae) incubated in soil amended with organic wastes. Fresen. Environ. Bull. 21 (2A), 441, 2012.
23. BAYLEY M., OVERGAARD J., HOJ A.S., MALMENDAL A., NIELSEN N.C., HOLMSTRUP M., WANG T. Metabolic changes during estivation in the common earthworm Aporrectodea caliginosa. Physiol. Biochem. Zool. 83 (3), 541, 2010.

24. MUSAIDA M.M.M., PHIRI A., CHIRINDA N., MUREDZI P., GOVHAAND J., SENGUDZWA T. Vermicomposting of waste corn pulp blended with cow dung manure using Eisenia fetida. International Journal of Chemical, Molecular, Nuclear, Materials and Metallurgical Engineering. 6 (8), 1080, 2012.

25. ASADOLLAHFARDI G., MOHEBI A. Fruits and vegetables residue vermicomposting using earthworm Eisenia fetida. J. Int. Environ. Appl. Sci. 7 (2), 261, 2012.

26. MUTHUKUMARAVEL K., AMSATH A., SUKUMARAN M. Vermi-composting of vegetable wastes using cow dung. E-J. Chem. 5 (4), 810, 2008.

27. ANSARI A.A., RAJPERSAUD J. Physicochemical changes during vermicomposting of water hyacinth (Eichhornia crassipes) and grass clippings. International Scholarly Research Notices Soil Science. 2012, 1, 2012.

28. BASTARDO L., SANCHEZ R., MARCO PARRA L., RIOS Y., SEGURA Y., TORRES G. Vermicompost enriched in calcium from the ash of sugar cane bagasse and biological behavior of Eisenia fetida. Rev. Fac. Agron. LUZ. 31 (1), 138, 2014.

29. SAHARIAH B., GOSWAMI L., KIM K-H., BHATTACHARYYA P., BHATTACHARYYA S.S. Metal remediation and biodegradation potential of earthworm species on municipal solid waste: a parallel analysis between Metaphire posthuma and Eisenia fetida. Bioresour. Technol. 180, 230, 2015.

30. RAVINDRAN B., MNKENI P.N.S. Bio-optimization of the carbon-to-nitrogen ratio for efficient vermicomposting of chicken manure and waste paper using Eisenia fetida. Environ. Sci. Pollut. Res. 23 (17), 16965, 2016.

31. MUPAMBWA H.A., MNKENI P.N.S. Eisenia fetida stocking density optimization for enhanced bioconversion of fly ash enrichedvermicompost. J. Environ. Qual. 45 (3), 1087, 2016.

32. OSKIN B. Invasive earthworms harming great lakes forests. Available online: http://www.livescience.com/40767invasive-earthworms-harming-forests.html (accessed 06 March 2017).

33. OSKIN B. Invasive earthworms harming great lakes forests. Available at http://www.livescience.com/40767-invasive-earthworms-harming-forests.html (accesed March 2017). 2013

34. SUTHAR S., GAIROLA S. Nutrient recovery from urban forest leaf litter waste solids using Eisenia fetida. Ecol. Eng. 71, 660, 2014.

35. SANGWAN P., KAUSHIK C.P., GARG V.K. Vermiconversion of industrial sludge for recycling the nutrients. Bioresour. Technol. 99 (18), 8699, 2008.

36. PATTNAIK S., REDDY M.V. Nutrient status of vermicompost of urban green waste processed by three earthworm species - Eisenia fetida, Eudrilus eugeniae, and Perionyx excavatus. Appl. Environ. Soil. Sci. 2010, 1, 2009.

37. ZIRBES L., RENARD Q., DUFEY J., KHANH TU P., DUYET H.N., LEBAILLY P., FRANCIS F., HAUBRUGE É. Valorisation of a water hyacinth in vermicomposting using an epigeic earthworm Perionyx excavatus in Central Vietnam. Biotechnol. Agron. Soc. 15 (1), 85, 2011.

38. LIU X., HU C., ZHANG S. Effects of earthworm activity on fertility and heavy metal bioavailability in sewage sludge. Environ. Int. 31 (6), 874, 2005. 
39. KASHI G., KHOSHAB F. Vermicomposting of municipal solid waste: A biophysicochemical characteristics. Donnish J. Agric. Res. 2 (4), 27, 2015.

40. KIM Y.N., ROBINSON B., LEE K.A. Interactions between earthworm burrowing, growth of a leguminous shrub and nitrogen cycling in a former agricultural soil. Appl. Soil. Ecol. 111, 79, 2017.
41. ZHANG W.W., CAO J., ZHANG S.D., WANG C. Effect of earthworms and arbuscular mycorrhizal fungi on the microbial community and maize growth under salt stress. Appl. Soil. Ecol. 107, 214, 2016. 